\title{
ROLE OF RHO FAMILY GTP-BINDING PROTEINS IN IgE RECEPTOR-MEDIATED PHOSPHOLIPASE D ACTIVATION IN MAST CELLS
}

\author{
Katsuhiro Ojio ${ }^{1,4}$, Yoshiko Banno ${ }^{2}$, Kazuki Hayakawa ${ }^{1}$, Yatsuji Ito ${ }^{1}$, NaOki Kato ${ }^{3}$, Kunitomo \\ WATANABE ${ }^{3}$, Hideo MiYATA ${ }^{1}$ and Yoshinori NOZAWA ${ }^{2}$ \\ ${ }^{1}$ Department of Otolaryngology, ${ }^{2}$ Department of Biochemistry, and ${ }^{3}$ Institute of Anaerobic Bacteriology, Gifu University School of \\ Medicine, Tsukasamachi 40, Gifu 500-8705, Japan
}

\begin{abstract}
To investigate the role of Rho family proteins in antigen-mediated phospholipase D (PLD) activation in cultured rat basophilic leukemia (RBL-2H3) mucosal mast cells, we used two toxins, Clostridium difficile toxin B (toxin B) and Clostridium botulinum C3 toxin (C3 toxin), which inhibit Rho family proteins by monoglucosylation and ADP-ribosylation, respectively. Pretreatment with toxin B caused rounding-out of RBL-2H3 cells, strong inhibition of antigen-induced PLD activation, and also a complete blockage of serotonin secretion. By contrast, C3 toxin was without effect on both PLD activation and serotonin secretion, although RhoA was markedly ADP-ribosylated. Recombinant ADP-ribosylation factor (Arf) stimulated the PLD activity in isolated membranes in a dose-dependent manner, and $4 \beta$-phorbol 12-myristate 13-acetate (PMA) pretreatment of cells potentiated this recombinant Arf effect. The recombinant Arf- and PMA-stimulated PLD activities were partially inhibited by pretreatment with toxin B but not by C3 toxin. Stimulation of RBL cells with antigen induced translocation to membranes of factors involving PLD activation, e.g. protein kinase $\mathrm{C}(\mathrm{PKC})(\alpha, \beta 2, \delta, \varepsilon)$ isozymes, Cdc42 and Arf, but not RhoA. These results suggest that the membrane-translocation of $\mathrm{Cdc} 42$ plays a major role in antigen-induced PLD activation in RBL cells and also that the translocated Arf and PKCs exert a co-operative effect for PLD activation.
\end{abstract}

\footnotetext{
Abbreviations: PLD, phospholipase $\mathrm{D} ; \mathrm{RBL}$, rat basophilic leukemia; Toxin $\mathrm{B}$, Clostridium difficile Toxin B; C3 toxin, Clostridium botulinum C3 toxin; Arf, ADP-ribosylation factor; PMA, $4 \beta$-phorbol $12-$ myristate 13-acetate; PKC, protein kinase C; FceRI, high affinity $\mathrm{IgE} \mathrm{Fc}$ receptor; $\mathrm{PA}$, phosphatidic acid; DG, 1,2-diacylglycerol; G protein, GTP-binding proteins; GST, glutathione $S$-transferase; DNP, 2,4-dinitrophenyl; MEM, minimum essential medium; FBS, fetal bovine serum; serotonin, 5-hydroxytryptamine; NAD, nicotinamide adenine dinucleotide; GTP $\gamma \mathrm{S}$, guanosine $5^{\prime}$-O-(3-thiotriphosphate); PBut, phosphatidylbutanol; EGTA, $O, O^{\prime}$-bis(2-aminoethyl) ethyleneglycol- $N, N, N^{\prime}$ $N^{\prime}$-tetraacetic acid; DTT, dithiothreitol; IPs, inositol phosphates; SDS, sodium dodecyl sulfate; CD, cytochalasin D; PI-PLC, phosphoinositide-specific phospholipase $C$
}

Upon antigen stimulation, cross-linking of receptor-IgE complexes induces release of chemical mediators such as histamine, serotonin, leukotorienes and prostaglandins. Rat basophilic leukemia (RBL) cells share many of the properties of mucosal mast cells and are widely used as a model for the study of high affinity $\operatorname{IgE} F \mathrm{~F}$ receptor (FcERI)-mediated signaling events. Aggregation of FceRI leads to activation of various signal-transducing phospholipases $(1,16,23)$. Hydrolysis of phosphatidylcholine by phospholipase D (PLD) produces phosphatidic acid (PA), which can be fur-

${ }^{4}$ Correspondence to: $\mathrm{K}$. Ojio at the above address. Email: ojioka@cc.gifu-u.ac.jp; Tel: (81) 58-267-2230; Fax: (81) 58-265-9002 
ther converted to 1,2-diacylglycerol (DG) by phosphohydrolase $(3,9)$. Since both PA and DG have been shown to act as second messengers $(2,10$, 29), PLD has been believed to play an important role in cellular signaling. Recently, there has been increasing evidence that PLD is activated by several regulatory factors (10). For example, two small GTP-binding proteins (G protein), ADP-ribosylation factor (Arf) and Rho family, mainly RhoA were shown to be the potent factors for PLD activity in various cell types $(2,10,29)$.

On the other hand, the Rho family proteins, Rho, Rac and $\mathrm{Cdc} 42$ are involved in the formation of actin stress fibers, lamellipodia and filopodia, respectively $(12,30,44)$. In association with such cytoskeletal reorganization, these proteins partake in regulation of smooth muscle contraction, transcription and cell proliferation. It has also been shown that protein kinases, lipid kinases and phospholipases are implicated in the Rho signaling pathway $(7,33,44)$. Recently, Prepens et al. (37) indicated that $\mathrm{Cdc} 42$, but not RhoA was a principal factor in FceRI-mediated serotonin secretion in RBL cells by using two bacterial toxins. It has been known that Clostridium difficile toxins $\mathrm{A}$ and $B$ block the functions of Rho family proteins (Rho, $\mathrm{Rac}$ and $\mathrm{Cdc} 42$ ) by monoglucosylation at $\mathrm{Thr}^{37}$ $(17,18)$ and Clostridium botulinum $\mathrm{C} 3$ toxin $(\mathrm{C} 3$ toxin) blocks Rho by ADP-ribosylation at $\mathrm{Asn}^{41}$ (17). Our previous study has demonstrated that antigen-mediated PLD activation in RBL cells was suppressed by toxin B (34), suggesting that Rho family proteins are involved in the PLD activating process.

The present study was designed to gain further insight into the mechanism for the antigen-stimulated PLD activation in RBL cells by using two bacterial toxins (toxin B and C3 toxin). The results presented here have suggested that $\mathrm{Cdc} 42$ rather than Rho A plays a major role in antigen-stimulated PLD activation in RBL cells.

\section{MATERIALS AND METHODS}

\section{Materials}

Toxin B purified from C. difficile VPI 10463 was kindly supplied by Dr David M. Lyerly (VPI Corporate Research Center, VA). E. coli bearing the glutathione $S$-transferase (GST)-C3 toxin plasmid was a kind gift from Dr Alan Hall (University College London, U.K.). E. coli bearing Arf1 plasmid was a kind gift from Dr Joel Moss (National Institutes of Health, MD). Monoclonal mouse anti-2,4- dinitrophenyl (DNP) IgE was obtained from Seikagaku Kogyo (Tokyo, Japan). Ascaris suum antigen coupled with 2,4-dinitrophenyl (DNP-Ascaris antigen) was prepared as described previously (16). Eagle's minimum essential medium (MEM), penicillin and streptomycin were obtained from Gibco Laboratories (Grand Island, NY). Fetal bovine serum (FBS) was purchased from Irvine Scientific (Santa Ana, CA). $\left[{ }^{14} \mathrm{C}\right] 5$-Hydroxytryptamine (serotonin) $(50 \mu \mathrm{Ci} / \mathrm{mmol}),\left[{ }^{32} \mathrm{P}\right]$ nicotinamide adenine dinucleotide (NAD) $(30 \mathrm{Ci} / \mathrm{mmol})$, and Aquasol-2 were purchased from Dupont-New England Nuclear (Boston, MA). $\left[9,10-{ }^{3} \mathrm{H}\right]$ Palmitic acid $(52.4 \mathrm{Ci} / \mathrm{mmol}), \quad$ myo- $\left[2-{ }^{3} \mathrm{H}\right]$ inositol $\quad(18.2 \mathrm{Ci} /$ $\mathrm{mmol})$, UDP-[U- $\left.{ }^{14} \mathrm{C}\right]$ glucose $(0.3 \mathrm{Ci} / \mathrm{mmol})$, the enhanced chemiluminescence system and anti-rabbit IgG horseradish peroxidase-coupled secondary antibodies were from Amersham International (Buckinghamshire, U.K.). Dowex AG1-X8 (200400 mesh, formate form) was obtained from BioRad Laboratories (Richmond, CA). 4 $\beta$-Phorbol 12myristate 13-acetate (PMA) was from Sigma (St. Louis, MO). Guanosine 5'-O-(3-thiotriphosphate) $(\mathrm{GTP} \gamma \mathrm{S})$ was from Boehringer Mannheim Gmbh (Mannheim, Germany). Silica gel LK6D plates were from Whatmann (Clifton, NJ). Antibodies against small $\mathrm{G}$ proteins (RhoA, Rac1, Cdc42Hs) and PKC isozymes were from Santa Cruz Biotechnology (Santa Cruz, CA). Phosphatidylbutanol (PBut) standard was obtained from Avanti (Albaster, AL). All other reagents used were of the highest analytical grade.

\section{Cell Culture}

Monolayer cultures of RBL cells were maintained in MEM supplemented with $10 \%$ heat-inactivated FBS, penicillin (100 units $/ \mathrm{ml}$ ) and streptomycin $(100 \mu \mathrm{g} / \mathrm{ml})$ in a humidified atmosphere of $95 \%$ air $/ 5 \% \mathrm{CO}_{2}$ at $37^{\circ} \mathrm{C}(1,23)$. For detection of translocation to membranes of PKC isozymes and $\mathrm{G}$ proteins, cells were incubated in MEM with $1 \%$ heat-inactivated FBS, penicillin and streptomycin for $12 \mathrm{~h}$ before stimulation.

\section{Assay of Glucosylation and ADP-Ribosylation Activities}

Glucosylation of proteins by toxin B in RBL cell lysates was performed by the method described by Just et al. (17), with minor modifications. For measurement of glucosylation, RBL cells were pretreated with $5 \mathrm{ng} / \mathrm{ml}$ toxin $\mathrm{B}$ for $4 \mathrm{~h}$, and then lysed 
by sonication. The lysates ( $1 \mathrm{mg}$ protein/ml) were incubated with $1 \mu \mathrm{g} / \mathrm{ml}$ toxin $\mathrm{B}$ in the presence of $30 \mu \mathrm{M}$ UDP $-\left[{ }^{14} \mathrm{C}\right]$ glucose at $37^{\circ} \mathrm{C}$ for $40 \mathrm{~min}$.

Unlike toxin $\mathrm{B}, \mathrm{C} 3$ toxin can be hardly incorporated into RBL cells. Therefore, we used the scrape-loading method which has been used to incorporate macromolecules into adherent cells (26). RBL cells were gently scraped from dishes by rubber policemen in the presence of $2 \mu \mathrm{g} / \mathrm{ml} \mathrm{C} 3$ toxin in MEM and then incubated for $12 \mathrm{~h}$ (24). During the incubation time, the cells touched the dish again. The cells thus treated with $\mathrm{C} 3$ toxin were scraped and sonicated for measurement of ADP-ribosylation of Rho, and the lysates $(1 \mathrm{mg}$ protein $/ \mathrm{ml}$ ) were incubated with $10 \mu \mathrm{g} / \mathrm{ml} \mathrm{C} 3$ toxin in the presence of $10 \mu \mathrm{M}\left[{ }^{32} \mathrm{P}\right] \mathrm{NAD}$ at $37^{\circ} \mathrm{C}$ for 30 min. Aliquots mixed in Laemmli's sample buffer were subjected to electrophoresis on $13 \%$ polyacrylamide gel. Incorporations of UDP- $\left[{ }^{14} \mathrm{C}\right]$ glucose and $\left[{ }^{32} \mathrm{P}\right]$ NAD were measured by a bioimaging analyzer (Fuji FUJIX BAS 2000) and autoradiography, respectively.

\section{Assay of PLD Activity}

Intact cells The PLD activity in response to antigen was determined by measuring the formation of $\left[{ }^{3} \mathrm{H}\right] \mathrm{PBut}$ in the presence of butanol $(0.3 \%$, $\mathrm{v} / \mathrm{v})$ as described previously (19). RBL cells ( $1.5 \times$ $10^{6}$ cells $/ 35-\mathrm{mm}$ dishes) were labeled with $\left[{ }^{3} \mathrm{H}\right]$ palmitic acid $(2 \mu \mathrm{Ci} / \mathrm{dish})$ for $12 \mathrm{~h}$. For sensitization, anti-DNP IgE $(0.3 \mu \mathrm{g} / \mathrm{ml})$ was incubated for $2 \mathrm{~h}$ before stimulation. After removal of the radiolabeling medium, the dishes were rinsed three times and equilibrated in Tyrode-Hepes solution $\left(134 \mathrm{mM} \mathrm{NaCl}, 12 \mathrm{mM} \mathrm{NaHCO}_{3}, 2.9 \mathrm{mM} \mathrm{KCl}, 1\right.$ $\mathrm{mM} \mathrm{MgCl} 2,1.8 \mathrm{mM} \mathrm{CaCl}, 0.36 \mathrm{mM} \mathrm{NaH} \mathrm{PO}_{4}$, $5.6 \mathrm{mM}$ glucose, $10 \mathrm{mM}$ Hepes and $0.1 \% \mathrm{BSA} ; \mathrm{pH}$ 7.4). After this preincubation in Tyrode-Hepes solution containing $0.3 \%$ butanol for $5 \mathrm{~min}$, cells were stimulated with $100 \mathrm{ng} / \mathrm{ml}$ DNP-Ascaris antigen in the presence of butanol $(0.3 \%)$ for $20 \mathrm{~min}$.

The reactions were stopped by removing medium, followed by the immediate addition of $1 \mathrm{ml}$ of ice-cold PBS/methanol $(2: 5, \mathrm{v} / \mathrm{v})$ mixture to the cultured dishes. Cells were gently scraped with rubber policemen from the dishes with an additional $1 \mathrm{ml}$ of $\mathrm{PBS} / \mathrm{methanol} \mathrm{mixture,} \mathrm{and} \mathrm{then} \mathrm{trans-}$ ferred to a tube containing $0.7 \mathrm{ml}$ of chloroform. The lipid extraction was performed according to the method of Bligh and Dyer $(4) .\left[{ }^{3} \mathrm{H}\right] \mathrm{PB}$ But was separated on silica gel LK6D thin-layer plate in a solvent system of the upper phase of ethyl acetate /2, 2,4 - trimethylpentane / acetic acid / water $(13: 2: 3: 10, \mathrm{v} / \mathrm{v})(22)$. The area corresponding to $\left[{ }^{3} \mathrm{H}\right] \mathrm{PBut}$ was scraped off the plate and the radioactivity was determined in a liquid scintillation counter (Beckmann LS 6500).

Isolated membranes RBL cells $\left(2 \times 10^{6}\right.$ cells $/ 100 \mathrm{~mm}$ dish) were labeled with $\left[{ }^{3} \mathrm{H}\right]$ palmitic acid $(5 \mu \mathrm{Ci} / \mathrm{dish})$ for $12 \mathrm{~h}$. After removal of the radiolabeling medium, the dishes were rinsed three times in Tyrode-Hepes solution. In some experiments, the cells were treated with PMA (100 nM) for $15 \mathrm{~min}$ and then scraped in $10 \mathrm{ml}$ of ice-cold PBS containing $1 \mathrm{mM} \quad O, O^{\prime}$-bis (2-aminoethyl) ethyleneglycol- $N, N, N^{\prime}-N^{\prime}$-tetraacetic acid (EGTA). After centrifugation, the control and PMA-treated cells were resuspended in ice-cold buffer $\mathrm{A}(25$ $\mathrm{mM}$ Hepes, pH 7.4, $100 \mathrm{mM} \mathrm{KCl,} 3 \mathrm{mM} \mathrm{NaCl}, 5$ $\mathrm{mM} \mathrm{MgCl}_{2}, 0.5 \mathrm{mM}$ phenylmethylsulfonyl fluoride, $5 \mathrm{mM}$ dithiothreitol (DTT), $10 \mu \mathrm{g} / \mathrm{ml} \mathrm{leu-}$ peptin and $1 \mathrm{mM}$ EGTA) and were lysed by $\mathrm{N}_{2}$ cavitation. The membranes from PMA-untreated (control membranes) and PMA-treated (PMAmembranes) cells were collected by centrifugation at $100,000 \times g$ for $30 \mathrm{~min}$ and were resuspended in the buffer A. Control and PMA-membranes $(40 \mu \mathrm{g})$ were incubated at $37^{\circ} \mathrm{C}$ for $30 \mathrm{~min}$ in $100 \mu \mathrm{l}$ of the reaction buffer $(25 \mathrm{mM}$ Hepes, $\mathrm{pH} 7.4,100 \mathrm{mM}$ $\mathrm{KCl}, 3 \mathrm{mM} \mathrm{NaCl}, 6 \mathrm{mM} \mathrm{MgCl}$, $5 \mathrm{mM}$ DTT, $1 \mathrm{mM}$ EGTA, $1 \mathrm{mM}$ ATP, $0.3 \%$ butanol and $1 \mu \mathrm{M} \mathrm{Ca}^{2+}$ ) in the presence of $100 \mu \mathrm{M}$ GTP $\gamma \mathrm{S}$ and $5 \mu \mathrm{M}$ recombinant Arf. The lipid extraction and determination of radioactivity in $\left[{ }^{3} \mathrm{H}\right] \mathrm{PB}$ ut were performed as described above.

\section{Serotonin Release}

RBL cells were labeled with $\left[{ }^{14} \mathrm{C}\right]$ serotonin $(10$ $\mathrm{nCi} / 1.5 \times 10^{5}$ cells) for $12 \mathrm{~h}$ at $37^{\circ} \mathrm{C}$. For sensitization, anti-DNP $\operatorname{IgE}(0.3 \mu \mathrm{g} / \mathrm{ml})$ was incubated for 2 $\mathrm{h}$ before stimulation. After removal of the radiolabeling medium, the dishes were rinsed three times and equilibrated in Tyrode-Hepes solution for 5 $\min$ at $37^{\circ} \mathrm{C}$. The cells were then stimulated for 20 min with $100 \mathrm{ng} / \mathrm{ml}$ DNP-Ascaris antigen. Incubation was stopped by removing the medium, followed by addition of $0.2 \mathrm{ml}$ of ice-cold PBS with $1 \%$ TritonX-100. The radioactivities in the medium and the cells (TritonX-100 extract) were determined in a liquid scintillation counter (Beckmann LS 6500, Fullerton, CA) in $5 \mathrm{ml}$ of Aquasol-2. $\left[{ }^{14} \mathrm{C}\right]$ Serotonin release was determined as percent of the radioactivity in the medium to the total radioactivity. 

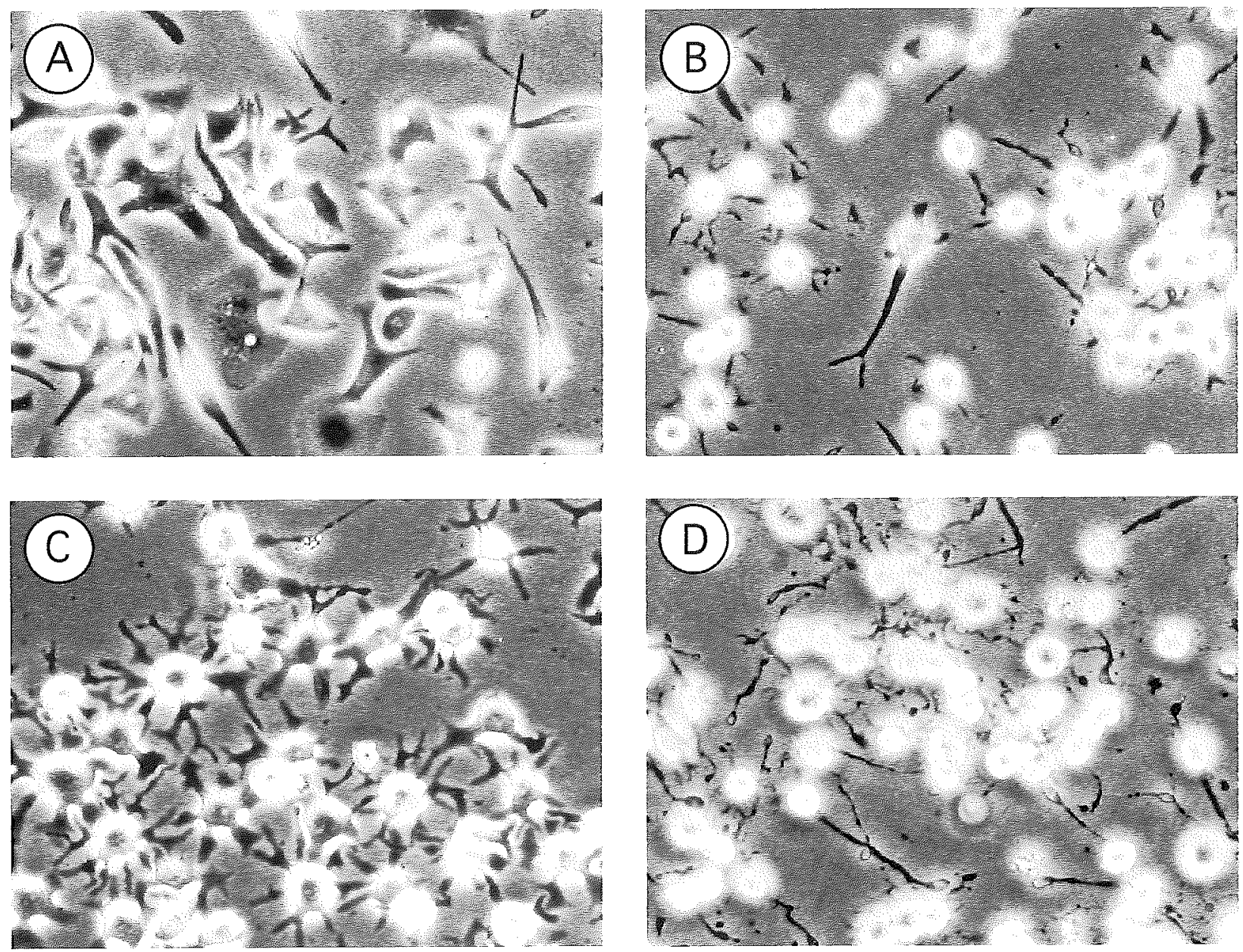

Fig. 1 Morphological changes of RBL-2H3 cells treated with $C$. difficile toxin $\mathrm{B}, C$. botulinum $\mathrm{C} 3$ toxin and cytochalasin D. Cells were incubated with $5 \mathrm{ng} / \mathrm{ml}$ of toxin B for $4 \mathrm{~h}$ (B) or with $10 \mu \mathrm{M}$ of cytochalasin D for $1 \mathrm{~h}$ (D). For incorporation of $\mathrm{C} 3$ toxin, RBL cells were gently scraped from dishes by rubber policeman in the presence of the medium containing $2 \mu \mathrm{g} / \mathrm{ml} \mathrm{C} 3$ toxin and further incubated in the same medium for $12 \mathrm{~h}$ (C). The control cells (A) were incubated without toxins for $12 \mathrm{~h}$. Similar results were obtained with two additional and different cell preparations and showed at $\times 100$ of original magnification.

\section{Measurement of Phosphoinositide Hydrolysis}

$\left[{ }^{3} \mathrm{H}\right]$ Inositol phosphates were separated by anionexchange column chromatography (5). RBL cells $\left(1.5 \times 10^{6}\right.$ cells/dish $)$ in $35 \mathrm{~mm}$ dishes were labeled with $\left[{ }^{3} \mathrm{H}\right]$ myo-inositol $(1 \mu \mathrm{Ci} / \mathrm{ml})$ in inositol-free MEM for $12 \mathrm{~h}$. For sensitization, anti-DNP IgE $(0.3 \mu \mathrm{g} / \mathrm{ml})$ was incubated for $2 \mathrm{~h}$ before stimulation. After removal of the radiolabeling medium, the dishes were rinsed three times and equilibrated in Tyrode-Hepes solution. After this preincubation in Tyrode-Hepes solution containing $10 \mathrm{mM} \mathrm{LiCl}$ for $15 \mathrm{~min}$, the cells were stimulated with antigen for $10 \mathrm{~min}$. The reactions were terminated by the addition of $0.5 \mathrm{ml}$ of ice-cold $10 \%$ perchloric acid.
The cells were scraped and $\mathrm{pH}$ was adjusted to 7.4 with $1.53 \mathrm{M} \mathrm{KOH}$ solution containing $75 \mathrm{mM}$ Hepes. After being kept on ice for $1 \mathrm{~h}$, the formed $\mathrm{KClO}_{4}$ was sedimented by centrifugation at 1,600 $\times g$ for $10 \mathrm{~min}$ at $4^{\circ} \mathrm{C}$. The resulting supernatant was diluted with $10 \mathrm{ml}$ of water and applied onto a Dowex 1-X8 column (200-400 mesh). Inositol phosphates (IPs) were eluted with an ammonium formate gradient for radioactivity measurement.

\section{Translocation to Membranes of Protein Kinase $C(P K C)$ Isozymes and Low Molecular Weight $G$ Proteins}

To examine translocation to membranes of PKC 


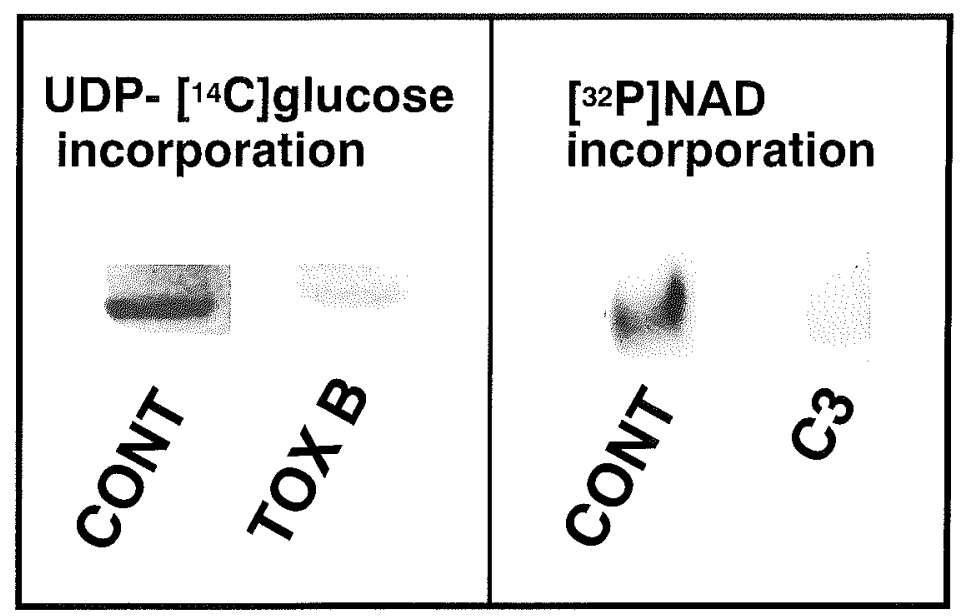

Fig. 2 Glucosylation and ADP-ribosylation of Rho family proteins by toxin B and C3 toxin in RBL-2H3 cells. RBL-2H3 cells were pretreated with $5 \mathrm{ng} / \mathrm{ml}$ toxin $\mathrm{B}$ for $4 \mathrm{~h}$. For incorporation of C3 toxin, RBL cells were gently scraped from dishes by rubber policeman in the presence of the medium containing $2 \mu \mathrm{g} / \mathrm{ml} \mathrm{C} 3$ toxin and then incubated in the same medium for $12 \mathrm{~h}$. After cell lysis, incorporation of UDP- $\left[{ }^{14} \mathrm{C}\right]$ glucose or $\left[{ }^{32} \mathrm{P}\right] \mathrm{NAD}$ was measured as described in the 'Materials and Methods'. The results were representative of three different experiments.

isozymes and low molecular weight $\mathrm{G}$ proteins, RBL cells stimulated with antigen were lysed by $\mathrm{N}_{2}$ cavitation in buffer $\mathrm{A}$ and the membrane fractions were collected by centrifugation at $100,000 \times$ $g$ for $30 \mathrm{~min}$. The membranes $(10 \mu \mathrm{g}$ protein for $\mathrm{PKC}$ and $50 \mu \mathrm{g}$ protein for $\mathrm{G}$ proteins) were resuspended in Laemmli's sample buffer (20) and subjected to electrophoresis on $8 \%$ and $13 \%$ sodium dodecyl sulfate (SDS)-polyacrylamide gels for PKC and G proteins, respectively. The separated proteins were electrotransferred onto polyvinylidine difluoride membranes and the membranes were probed with specific antibodies to PKC isozymes and $\mathrm{G}$ proteins. Detection was performed with the enhanced chemiluminescence system according to the manufacture's protocol. The density of protein bands was measured with a densitometer (Densitograph for the Macintosh ver.3.02, ATTO).

\section{Expression and Purification of Recombinant Proteins}

Recombinant GST-C3 toxin was expressed as GST fusion proteins in $E$. coli and purified on glutathione-Sepharose beads as described (31). Recombinant Arf was expressed in E. coli and purified by column chromatographies on DEAESephacel and Sephacryl S-300 columns as described (14). Purified GST-C3 toxin and Arf showed a single band on Coomassie-stained SDS- polyacrylamide gels, respectively.

\section{RESULTS}

\section{Effects of Toxin B and C3 Toxin on Cell Morphology and Rho Family Proteins}

To delineate the implication of Rho family proteins in the antigen-mediated signaling process in RBL cells, we examined the effects of two toxins, toxin $\mathrm{B}$ and $\mathrm{C} 3$ toxin. RBL cells were markedly responsive to toxin $\mathrm{B}$, which blocks Rho family proteins (Rho, Cdc42, Rac) by monoglucosylation. When added to the culture medium, morphological changes were induced. Cell shape changes were initiated $2 \mathrm{~h}$ after addition of toxin $\mathrm{B}(5 \mathrm{ng} / \mathrm{ml})$, followed by distinct rounding-out at $4 \mathrm{~h}$ (Fig. 1B). Since C3 toxin specific for Rho was difficult to enter the RBL cells, the method of scrape-loading was used in the presence of $\mathrm{C} 3$ toxin $(2 \mu \mathrm{g} / \mathrm{ml})$. This treatment with $\mathrm{C} 3$ toxin caused similar morphological changes (Fig. 1C). Rho family proteins have been known to be associated with actin polymerization (30). Treatment of RBL cells with cytochalasin D (CD) $(10 \mu \mathrm{M}, 1 \mathrm{~h})$, which causes depolymerization of the actin cytoskeleton (8), also induced similar rounding-out of cells (Fig. 1D).

It has been known that toxin B glucosylates Rho family proteins (Rho, Cdc42, Rac) (17), whereas C3 toxin ribosylates Rho. Our previous study indicated that RhoA and $\mathrm{Cdc} 42$, but not Racl were present in RBL cells (34). In control cells without 


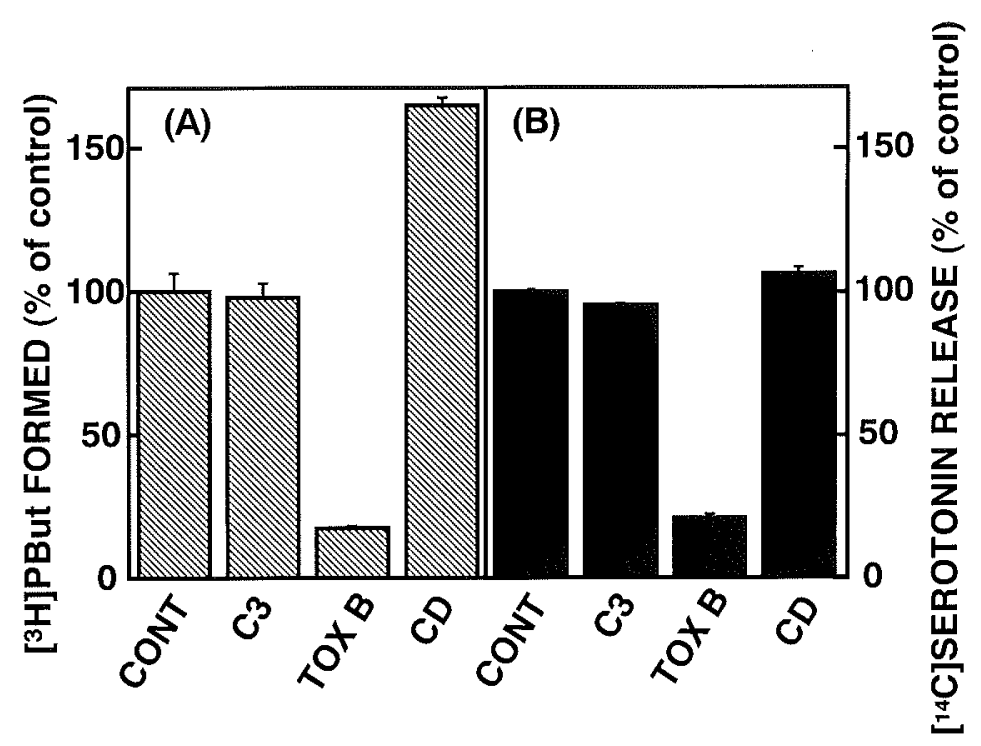

Fig. 3 Effects of toxin B, C3 toxin and CD on antigen-induced PLD activation (A) and serotonin secretion (B) in RBL-2H3 cells. (A) The [ ${ }^{3} \mathrm{H}$ ]palmitic acid-labeled cells were treated with $5 \mathrm{ng} / \mathrm{ml}$ toxin $\mathrm{B}$ for last $4 \mathrm{~h}$ or scrapeloaded in the presence of $2 \mu \mathrm{g} / \mathrm{ml} \mathrm{C} 3$ toxin for $12 \mathrm{~h}$ or treated with $10 \mu \mathrm{M}$ cytochalasin D for last $1 \mathrm{~h}$. The treated cells were then stimulated with $100 \mathrm{ng} / \mathrm{ml}$ antigen in the presence of $0.3 \%$ butanol for $20 \mathrm{~min}$. [ $\left.{ }^{3} \mathrm{H}\right] \mathrm{PBut}$ formation was determined as described under the 'Materials and Methods'. (B) RBL-2H3 cells were labeled with $\left[{ }^{14} \mathrm{C}\right] 5-\mathrm{HT}$ for $12 \mathrm{~h}$, and treated with $5 \mathrm{ng} / \mathrm{ml}$ toxin B for last $4 \mathrm{~h}$ or scrape-loaded in the presence of $2 \mu \mathrm{g} / \mathrm{ml} \mathrm{C} 3$ toxin for $12 \mathrm{~h}$ or treated with $10 \mu \mathrm{M}$ cytochalasin D for last $1 \mathrm{~h}$. The cells were then stimulated with $100 \mathrm{ng} / \mathrm{ml}$ antigen for $20 \mathrm{~min}$. $\left[{ }^{14} \mathrm{C}\right] 5$-HT release $(\%)$ was determined as described under the 'Materials and Methods'. Each point represents the mean $\pm \mathrm{SD}$ of two experiments, each performed in duplicate.

toxin $\mathrm{B}$ treatment, there was marked incorporation of UDP- $\left[{ }^{14} \mathrm{C}\right]$ glucose into the protein band of $M_{\mathrm{r}}$ $\sim 22 \mathrm{kDa}$ which was cross-reacted with anti-RhoA and $\mathrm{Cdc} 42$ (Fig. 2). However, by the pretreatment of cells with toxin B $(5 \mathrm{ng} / \mathrm{ml})$, the incorporation of UDP- $\left[{ }^{14} \mathrm{C}\right]$ glucose into the same protein band was greatly inhibited, indicating that these proteins were endogenously glucosylated by the toxin B pretreatment. There was marginal incorporation of [22 P]NAD into the $M_{\mathrm{r}} \sim 22 \mathrm{kDa}$ proteins in lysate from cells which had been treated with $\mathrm{C} 3$ toxin (2 $\mu \mathrm{g} / \mathrm{ml}$ ) for $12 \mathrm{~h}$, indicating that approximately $80 \%$ of RhoA was endogenously ribosylated by the C3 toxin pretreatment (Fig. 2).

\section{Effects of Toxin B, and C3 Toxin on Antigen-Mediated PLD Activity and Serotonin Secretion}

We have previously shown that toxin B suppressed antigen-induced $\left[{ }^{3} \mathrm{H}\right] \mathrm{PB}$ ut formation in RBL cells. In the current study, further experiments to delineate the preferential contribution of Rho family proteins in antigen-mediated PLD activation were performed by using two toxins, toxin $\mathrm{B}$ and $\mathrm{C} 3$ toxin. When control RBL cells labeled with $\left[{ }^{3} \mathrm{H}\right]$ palmitic acid were stimulated with antigen $(100 \mathrm{ng} / \mathrm{ml})$ in the presence of $0.3 \%$ butanol, $\left[{ }^{3} \mathrm{H}\right] \mathrm{PBut}$ formation, a potential parameter of PLD activity, was rapidly increased within first $2 \mathrm{~min}$, reaching a plateau at $10 \mathrm{~min}$ and remained unchanged for $30 \mathrm{~min}$ (data not shown). However, the treatment with $5 \mathrm{ng} / \mathrm{ml}$ toxin B for $4 \mathrm{~h}$ caused a marked inhibition of antigen-mediated PLD activity (Fig. 3A), suggesting the involvement of Rho family proteins in antigen-mediated PLD activation in RBL cells. In contrast, pretreatment of $\mathrm{C} 3$ toxin $(2 \mu \mathrm{g} / \mathrm{ml}, 12 \mathrm{~h})$ failed to suppress the PLD activity. Different effects of toxin B and C3 toxin were also observed in the antigen-stimulated serotonin secretion (Fig. 3B). Secretion was completely inhibited by toxin $\mathrm{B}$, but not affected by $\mathrm{C} 3$ toxin.

As described above, CD pretreatment of RBL cells at $10 \mu \mathrm{M}$ induced similar cell rounding-out as observed in the toxin treatments. This pretreatment rather potentiated (1.4-fold) antigen-mediated PLD activity and had no effect on antigen-stimulated serotonin secretion (Fig. 3). 


\section{Effects of Toxin B on Antigen-Induced Inositolphosphate Formation}

It has been reported that PLD is activated downstream of the phosphoinositide-specific phospholipase C (PI-PLC)/PKC activation $(45,46)$. To test this possibility, we have examined the effect of toxin B on PLC activity in RBL cells. When myo$\left[{ }^{3} \mathrm{H}\right]$ inositol-labeled RBL cells were stimulated with antigen $(100 \mathrm{ng} / \mathrm{ml})$ in the presence of $10 \mathrm{mM}$ $\mathrm{LiCl}$, IPs formation was increased 3.8-fold $(4.3 \%$ of total radioactivity) within $10 \mathrm{~min}$ of incubation (data not shown). However, toxin B pretreatment for $4 \mathrm{~h}$ showed a small reduction in the antigeninduced IPs formation (Fig. 4A). In sharp contrast, toxin $\mathrm{B}$ greatly suppressed the PLD activation (Fig. 4B).

\section{Effect of Recombinant Arf on PLD Activity in} Isolated Membranes

As another small molecular weight $\mathrm{G}$ protein, Arf is well accepted to be cofactor for PLD activation. Recently, Arf-dependent PLD (hPLD1) has been cloned and was shown to be synergistically activated by Rho family proteins and PKC (13). Our previous study in permeabilized RBL cells indicated that GTP $\gamma \mathrm{S}$ and PMA synergistically stimulated PLD activity (34). We have extended the previous work to further characterize the PLD activity. In this study, the effects of Arf were examined in the isolated membranes. Cells were pretreated with PMA $(100 \mathrm{nM})$ for $15 \mathrm{~min}$ to induce PKC translocation to membranes and then membranes were isolated (PMA-membranes). Similarly membranes were prepared from PMA-untreated control cells (control membranes). The PLD activity was greatly increased by addition of GTP $\gamma \mathrm{S}$ alone (without Arf) in PMA-membranes. Addition of recombinant Arf enhanced the GTP $\gamma$ S-dependent PLD activity in both control and PMA-membranes, suggesting the involvement of Arf and PKC for PLD activation (Fig. 5).

\section{Effects of Toxin B, C3 Toxin on GTP $\gamma S$ - Dependent PLD Activity in Membranes}

To assess the involvement of Rho family protein in the membrane-associated PLD activity of RBL cells, the effects of two toxins were examined (Fig. 6). The GTP $\gamma$ S-dependent PLD activity in control membranes was enhanced by addition of recombinant Arf $(5 \mu \mathrm{M})$. In the PMA-membranes, addi-

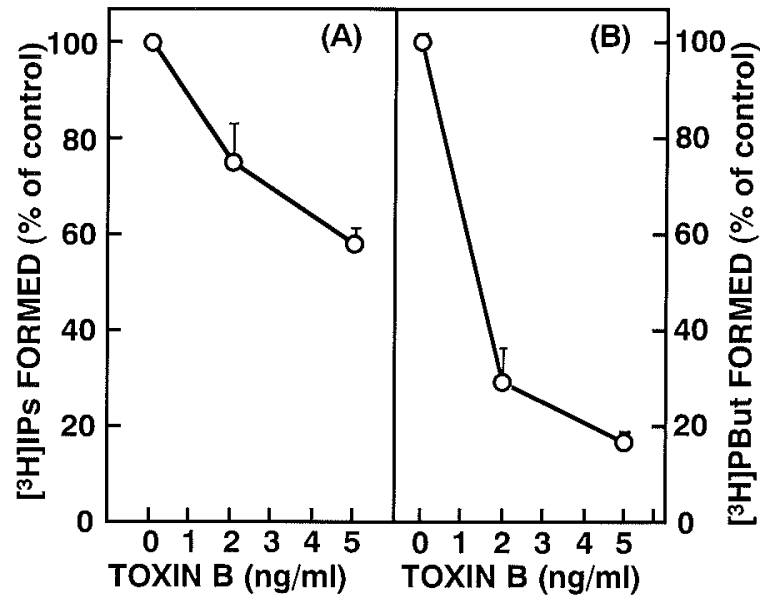

Fig. 4 Dose-dependent inhibition of antigen-induced IPs formation (A) and PLD activation by toxin B (B). (A) RBL-2H3 cells labeled with $\left[{ }^{3} \mathrm{H}\right] m y o$-inositol were preincubated with the indicated concentrations of toxin $\mathrm{B}$ for $4 \mathrm{~h}$ prior to stimulation. After preincubation in Tyrode-Hepes solution containing $10 \mathrm{mM} \mathrm{LiCl}$ for 15 min, the labeled cells were stimulated with $100 \mathrm{ng} / \mathrm{ml}$ antigen for $10 \mathrm{~min}$ in the presence of $10 \mathrm{mM} \mathrm{LiCl}$. $\left[{ }^{3} \mathrm{H}\right] \mathrm{IPs}$ formation was measured as described in the 'Materials and Methods'. (B) After preincubation with the indicated concentrations of toxin $B$ for $4 \mathrm{~h}$, $\left[{ }^{3} \mathrm{H}\right]$ palmitic acid-labeled cells were incubated in Tyrode-Hepes solution containing $0.3 \%$ butanol for 5 min and then stimulated with $100 \mathrm{ng} / \mathrm{ml}$ antigen for 20 min in the presence of $0.3 \%$ butanol. $\left[{ }^{3} \mathrm{H}\right] \mathrm{PBut}$ formation was determined as described under the 'Materials and Methods'. Each point represents the mean \pm SD of two experiments, each performed in duplicate.

tion of recombinant Arf caused a considerable elevation of the GTP $\gamma$ S-dependent PLD activity. However, pretreatment of the membranes with toxin B $(1 \mu \mathrm{g} / \mathrm{ml})$ for 30 min reduced the recombinant Arf-mediated PLD activation in control and PMA-membranes. In contrast, the $\mathrm{C} 3$ toxin treatment $(10 \mu \mathrm{g} / \mathrm{ml}$ for $30 \mathrm{~min})$ failed to suppress these membrane PLD activities but rather slightly enhanced.

\section{Membrane Translocation of Small Molecular Weight G Proteins and PKC Isozymes in Antigen-Stimulated RBL-2H3 Cells}

Recent studies have demonstrated that most of the activating factors of PLD exist in cytosol in unstimulated cells and translocate to membranes when cells are stimulated with agonists $(11,15)$. To examine membrane translocation of small molecular G proteins and PKC isozymes in antigen- 


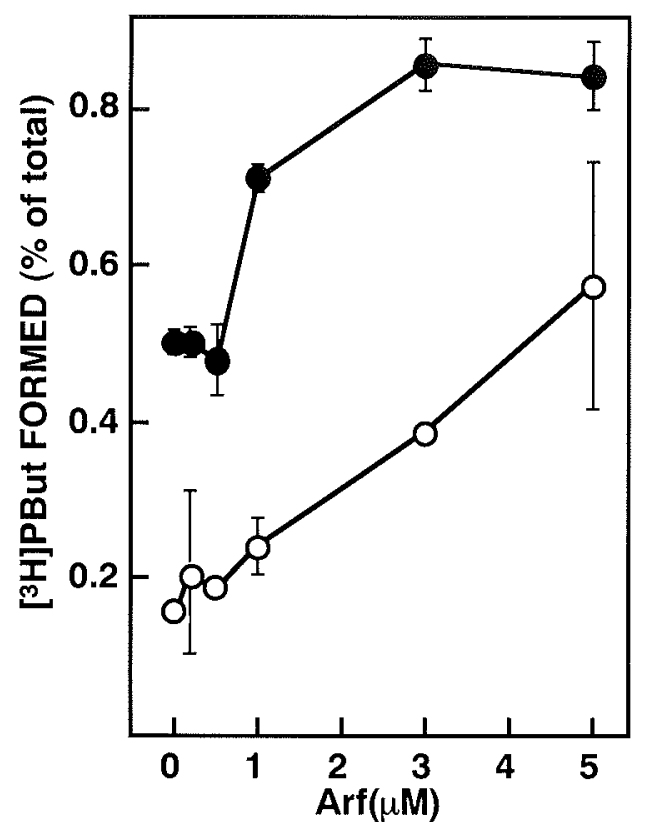

Fig. 5 Effect of Arf on GTP $\gamma \mathrm{S}$-induced PLD activation in RBL-2H3 cell membranes. $\left[{ }^{3} \mathrm{H}\right]$ Palmitic acidlabeled RBL-2H3 cells were pretreated with buffer $(\mathrm{O})$ or PMA (100 nM for $15 \mathrm{~min}$ ) (•) and lysed by $\mathrm{N}_{2}$ cavitation. The membranes from PMA-untreated (controlmembranes) and PMA-treated (PMA-membranes) cells were collected by centrifugation at $100,000 \times g$ for 30 min. Both membranes $(40 \mu \mathrm{g})$ were stimulated with the indicated concentrations of recombinant Arf in the presence of $100 \mu \mathrm{M} \mathrm{GTP} \gamma \mathrm{S}$ at $37^{\circ} \mathrm{C}$ for $30 \mathrm{~min}$. [ $\left.{ }^{3} \mathrm{H}\right] \mathrm{PBut}$ was measured as described under the 'Materials and Methods'. Each point represents the mean \pm SD of two experiments, each performed in duplicate.

stimulated RBL cells, the membrane fractions were isolated from stimulated and unstimulated cells with antigen for $15 \mathrm{~min}$. Western blotting analysis of $\operatorname{PKC}\left(\alpha, \beta_{2}, \delta, \varepsilon\right)$ isozymes and $\mathrm{G}$ proteins revealed that these proteins were markedly increased in the membranes after antigen-stimulation (Fig. 7). The membrane-associated PKC $\delta$ was most considerably increased after antigen-stimulation. $\mathrm{Cdc} 42$ and Arf were also redistributed to membranes by antigen-stimulation, but RhoA was much less translocated.

\section{DISCUSSION}

In the present study, we have demonstrated that Rho family proteins were involved in the antigenmediated PLD activation pathway in RBL cells by using two toxins, toxin $\mathrm{B}$ and $\mathrm{C} 3$ toxin. Toxin $\mathrm{B}$ monoglucosylates Rho, Rac and $\operatorname{Cdc} 42(17,18)$,

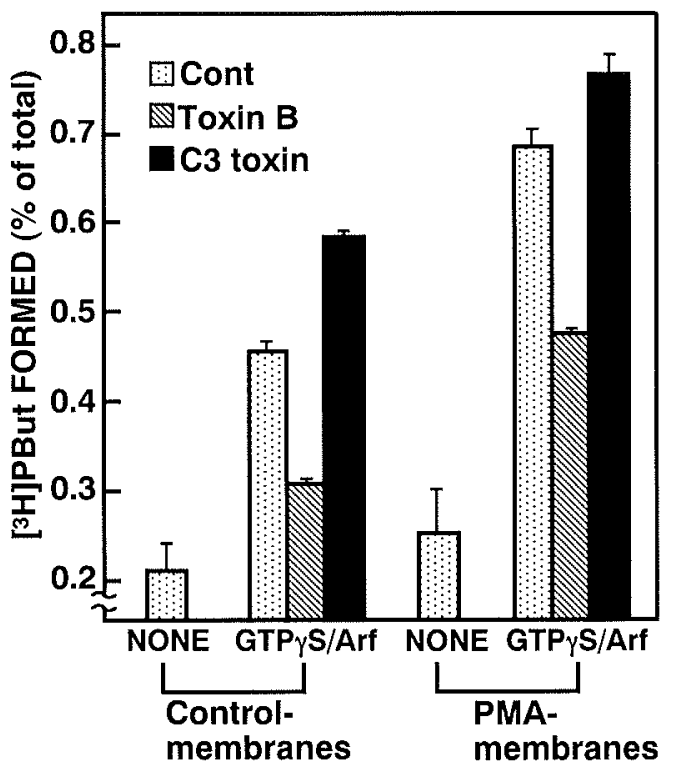

Fig. 6 Effects of toxin B and C3 toxin on the membrane-associated PLD activity in RBL-2H3 cells. The $\left[{ }^{3} \mathrm{H}\right]$ palmitic acid-labeled cells were pretreated with buffer or PMA (100 nM for $15 \mathrm{~min}$ ) and lysed by $\mathrm{N}_{2}$ cavitation. The membranes prepared from PMA-untreated (control-membranes) and PMA-treated (PMA-membranes) cells were treated with buffer ( $\square), 1 \mu \mathrm{g} / \mathrm{ml}$ toxin B (圆) or $10 \mu \mathrm{g} / \mathrm{ml} \mathrm{C} 3$ toxin ( $\mathrm{a}$ ) for $30 \mathrm{~min}$ and stimulated with recombinant Arf $(10 \mu \mathrm{M})$ in the presence of GTP $\gamma \mathrm{S}(100 \mu \mathrm{M})$ for $30 \mathrm{~min}$. Each point represents the mean $\pm \mathrm{SD}$ of two experiments, each performed in duplicate.

whereas C3 toxin ADP-ribosylates Rho (6). Thus, the toxins impair the functions of these $\mathrm{G}$ proteins. In contrast to $\mathrm{C} 3$ toxin, toxin $\mathrm{B}$ is feasible to enter RBL cells and induced disruption of the actin cytoskeleton at a very low concentration $(5 \mathrm{ng} / \mathrm{ml})$. The mechanism of cytotoxicity is well correlated with the observation that both toxins lead to disassembly of the actin filament network (27). Members of the Rho family proteins regulate the organization of the actin cytoskeleton (12); Rho controls the assembly of actin stress fibers and focal adhesion complexes (44), and Cdc42 stimulates formation of filopodia (30). It has been reported that toxin $\mathrm{B}$ and $\mathrm{CD}$ exert similar effects on the actin organization and assembly in various cells $(8,35)$. However, in contrast to strong inhibition of the antigen-induced PLD activation by toxin $\mathrm{B}$, the pretreatment with $\mathrm{CD}$ exerted a rather stimulatory effect in RBL cells. The difference in the effects of toxin $B$ and $C D$ was consistent with other works shown in the carbachol-stimulated PLD activation 


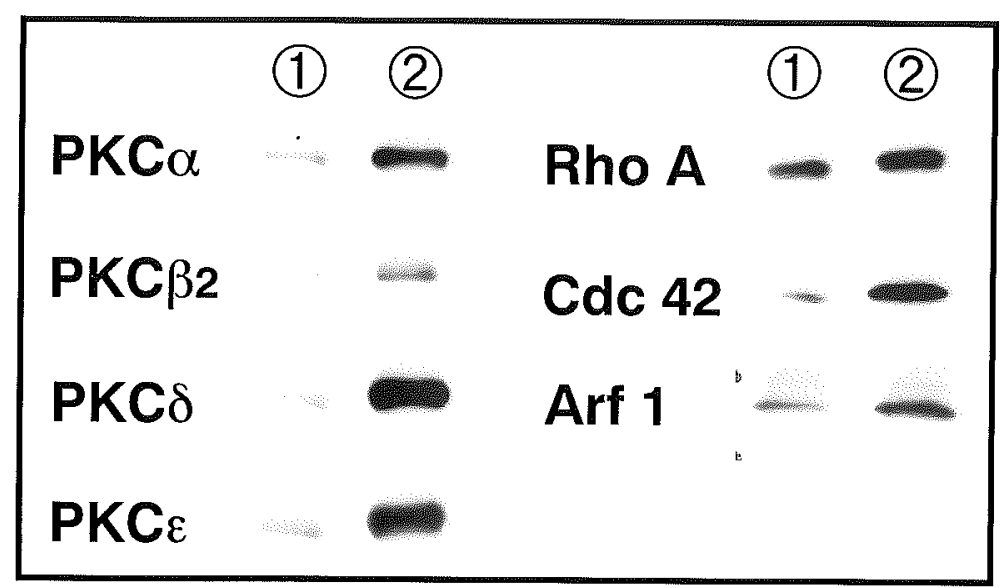

Fig. 7 Translocation of PKC isozymes and small molecular weight G proteins. Unstimulated (1) and antigen-stimulated for $15 \mathrm{~min}$ (2) RBL-2H3 cells were lysed by $\mathrm{N}_{2}$ cavitation in the lysis buffer. The membrane fractions were collected by centrifugation at $100,000 \times g$ for $30 \mathrm{~min}$ and resuspended in the lysis buffer. The membrane fractions mixed in Laemmli's sample buffer were subjected to electrophoresis on 8 and 13\% SDS-polyacrylamide gels for PKC and G proteins, respectively, and electrotransferred onto polyvinylidene difluoride membranes. The membranes were probed with specific antibodies for PKC isozymes or G proteins. Detection was performed with the ECL system according to the manufacture's protocol. The density of protein bands was measured with a densitometer.

in HEK cells (40) and antigen-stimulated serotonin secretion in RBL cells (37). Our present study suggested that antigen-induced PLD activation in RBL cells is mediated by the action of Rho family proteins independent of actin disassembly.

It has been reported that Rho A activates phosphatidylinositol-4-phosphate 5-kinase which synthesizes phosphatidylinositol 4,5-bisphosphate $\left(\mathrm{PIP}_{2}\right)(41)$. Several recent studies have indicated that $\mathrm{PIP}_{2}$ is an essential cofactor for PLD activity $(7,38)$. Therefore, it could be speculated that inhibition of Rho family proteins by toxin B could lead to a decrease in the $\mathrm{PIP}_{2}$ level in vivo. In HEK cells, toxin B inhibited carbachol-induced PLD activation and PI-PLC activation by reducing PIP $_{2}$ production (39). However, this may not be true with RBL cells. Toxin B showed only a small inhibitory effect (30\% inhibition) on antigen-mediated PI-PLC activation, whereas it caused almost complete inhibition of PLD activation. Therefore, it was conceivable that Rho family protein-dependent PLD activation did not occur downstream of PI-PLC activation and also that the $\mathrm{PIP}_{2}$ level was not largely decreased in toxin B-treated RBL cells. Indeed, inhibition of PLD activation by toxin B was not recovered by addition of $\mathrm{PIP}_{2}$ (data not shown).

Several in vitro experiments have demonstrated that members of Rho family proteins were differentially implicated in PLD activation depending on the cell type $(25,32,42,43)$. Usage of two toxins, toxin $\mathrm{B}$ and $\mathrm{C} 3$ toxin, was of advantage to understand the preferential contribution of Rho family proteins. For example, the inhibitory effect of toxin $\mathrm{B}$ on GTP $\gamma \mathrm{S}$-induced PLD activation was nearly equivalent to that induced by $\mathrm{C} 3$ toxin in permeabilized HEK cells (40), suggesting that Rho plays a principal role. On the other hand, antigeninduced serotonin secretion in RBL cells was inhibited by toxin $\mathrm{B}$, but not by $\mathrm{C} 3$ toxin, suggesting that $\mathrm{Cdc} 42$ rather than RhoA takes a main part (37). Our observations obtained here with these two toxins also indicated that Rho family proteins were involved in PLD activation in RBL cells. Toxin B caused a nearly complete inhibition of either the antigen-mediated PLD activation or Arfinduced PLD activation, whereas the treatment with $\mathrm{C} 3$ toxin, even though at least $80 \%$ of RhoA was ADP-ribosylated, failed to diminish the antigen-stimulated PLD activation and did not inhibit Arf-induced PLD activation. These results led us to assume that $\mathrm{Cdc} 42$ rather than RhoA takes a greater part in the antigen-mediated PLD activation in RBL cells. Recently, it was reported that agonist-induced PLD activation was due to the translocation to membranes of $\mathrm{G}$ proteins $(11,15)$. Indeed, it was shown that translocation to membranes of $\mathrm{Cdc} 42$ but not RhoA occurred upon antigen-stimulation of RBL cells.

We have previously demonstrated that the treat- 
ment of RBL cells with Breferdin A, a potent inhibitor of Arf activity, caused an inhibition of the antigen-induced PLD activation, suggesting the possibility of Arf implication (28). In this study, we demonstrated that the GTP $\gamma$ S-induced PLD activation was stimulated by recombinant Arf in isolated membranes of RBL cells and the membrane translocation of Arf was induced by antigenstimulation. Furthermore, the stimulatory effect of recombinant Arf was partially inhibited by toxin B pretreatment but not by $\mathrm{C} 3$ toxin, suggesting that Arf-induced PLD activation was dependent on Cdc42.

In addition to these $\mathrm{G}$ proteins, protein kinase $\mathrm{C}$ has also been known to be involved in PLD activation (10). Previously, we have shown that Rho A and PKC $\alpha$ synergistically activated the GTP $\gamma \mathrm{S}$ dependent PLD in HL60 cell membranes $(32,33)$. In permeabilized RBL cells, GTP $\gamma \mathrm{S}$ and PMA also synergistically activated PLD (34). Here we demonstrated that PLD activation by Arf in PMAmembranes was partially inhibited by toxin $B$, but not by $\mathrm{C} 3$ toxin, thus suggesting that PKC exerts a co-operative action in the Cdc42-dependent PLD activation pathway in RBL cells. Furthermore, recent study suggested that the PLD/PA phosphohydrolase process is necessary for secretion (21, 36). We also suggested in this study that $\mathrm{Cdc} 42$ may play an important role in secretion via PLD activation in RBL cells.

In summary, the results presented here suggested that $\mathrm{Cdc} 42$ would play a principal role in the antigen-induced PLD activation. However, to delineate the precise mechanisms, further extensive work including the reconstitution system using the purified proteins is required.

We thank Dr David M. Lyerly (VPI Corporate Research Center) for generous supply of $C$. difficile toxin $\mathrm{B}$ and Dr Joel Moss (National Institutes of Health) for kind supply of the Arfl plasmid and the anti-Arf antibody, and Dr Alan Hall (University College London) for generous gift of the E. coli bearing the GST-C3 toxin plasmid.

Received 25 November 1997; and accepted 17 December 1997

\section{REFERENCES}

1. Beaven M. A., Moore J. P., Smith G. A., Hesketh T. R. and Metcalfe J. C. (1984) The calcium signal and phosphatidylinositol breakdown in $2 \mathrm{H} 3$ cells. J. Biol. Chem. 259, $7137-7142$
2. Berridge M. J. and Irvine R. F. (1989) Inositol phosphates and cell signalling. Nature 341, 197-205

3. Billah M. M. and Anthes J. C. (1990) The regulation and cellular functions of phosphatidylcholine hydrolysis. Biochem. J. 269, 281-291

4. Bligh E. G. and Dyer W. J. (1959) A rapid method of total lipid extraction and purification. Can. J. Biochem. Physiol. 37, 911

5. Bone E. A., Fretten P., Palmer S., Kirk C. J. and Michell R. H. (1984) Rapid accumulation of inositol phosphates in isolated rat superior cervical sympathetic ganglia exposed to V1-vasopressin and muscarinic cholinergic stimuli. Biochem. J. 221, 803

6. Chardin P., Madaule P. and Tavitian A. (1988) Coding sequence of human tho cDNAs clone 6 and clone 9. Nucleic Acids Res. 16, 2717

7. Chong L. D., Traynor-Kaplan A., Bokoch G. M. and SchwarTZ M. A. (1994) The small GTP-binding protein Rho regulates a phosphatidylinositol 4-phosphate 5-kinase in mammalian cells. Cell 79, 507-513

8. CoOper J. A. (1987) Effects of cytochalasin and phalloidin on actin. J. Cell Biol. 105, 1473-1478

9. Exton J. H. (1990) Signaling through phosphatidylcholine breakdown. J. Biol. Chem. 265, 1-4

10. Exton J. H. (1994) Phosphatidylcholine breakdown and signal transduction. Biochim. Biophys. Acta 1212, 26-42

11. Fleming I. N., Elliott C. M. and Exton J. H. (1996) Differential translocation of Rho family GTPases by lysophosphatidic acid, endothelin-1, and platelet-derived growth factor. J. Biol. Chem. 271, 33067-33073

12. HALl A. (1994) Small GTP-binding proteins and the regulation of the actin cytoskeleton. Annu. Rev. Cell Biol. 10, $31-54$

13. Hammond S. M., Jenco J. M., Nakashima S., Cadwallader K., Gu Q., Cook S., Nozawa Y., Prestwich G. D., Frohman M. A. and Morris A. J. (1997) Characterization of two alternately spliced forms of phospholipase D1. Activation of the purified enzymes by phosphatidylinositol 4,5bisphosphate, ADP-ribosylation factor, and Rho family monomeric GTP-binding proteins and protein kinase $\mathrm{C} a . J$. Biol. Chem. 272, 3860-3868

14. Hong J. X., Haun R. S., Tsai S. C., Moss J. and Vaughan M. (1994) Effect of ADP-ribosylation factor amino-terminal deletions on its GTP-dependent stimulation of cholera toxin activity. J. Biol. Chem. 269, 9743-9745

15. Houle M. G., Kahn R. A., Naccache P. H. and BourGOIN S. (1995) ADP-ribosylation factor translocation correlates with potentiation of GTP $\gamma$ S-stimulated phospholipase D activity in membrane fractions of HL-60 cells. J. Biol. Chem. 270, 22795-22800

16. Ishizuka Y., Imai A. and Nozawa Y. (1984) Polyphosphoinositide turnover in rat mast cells stimulated by antigen: Rapid and preferential breakdown of phosphatidylinositol 4phosphate (DPI). Biochem. Biophys. Res. Commun. 123, 875-881

17. Just I., Selzer J., Wilm M., von Eichel-Streiber C., ManN M. and AKTORIES K. (1995) Glucosylation of Rho proteins by Clostridium difficile toxin B. Nature 375, 500-503

18. Just I., Wilm M., Selzer J., Rex G., von EichelStreiber C., ManN M. and Aktories K. (1995) The enterotoxin from Clostridium difficile (ToxA) monoglucosylates the Rho proteins. J. Biol. Chem. 270, 13932-13936 
19. Kumada T., Miyata H. and Nozawa Y. (1993) Involvement of tyrosine phosphorylation in $\mathrm{IgE}$ receptor-mediated phospholipase D activation in rat basophilic leukemia (RBL-2H3) cells. Biochem. Biophys. Res. Commun. 191, $1363-1368$

20. LaEmmLi U. K. (1970) Cleavage of structural proteins during the assembly of the head of bacteriophage T4. Nature 227, 680-685

21. Lin P. Y., Wiggan G. A. and Gilfillan A. M. (1991) Activation of phospholipase $D$ in a rat mast (RBL-2H3) cell line. A possible unifying mechanism for IgE-dependent degranulation and arachidonic acid metabolite release. $J$. Immunol. 146, 1609-1616

22. Liscovitch M. and Amsterdam A. (1989) Gonadotropinreleasing hormone activates phospholipase $\mathrm{D}$ in ovarian granulosa cells. Possible role in signal transduction. J. Biol. Chem. 264, 11762-11767

23. Maeyama K., Hohman R. J., Ali H., Cunha-Melo J. R. and BEAVEN M. A. (1988) Assessment of IgE-receptor function through measurement of hydrolysis of membrane inositol phospholipids. New insights on the phenomena of biphasic antigen concentration-response curves and desensitization. J. Immunol. 140, 3919-3927

24. Malcolm K. C., Elliott C. M. and Exton J. H. (1996) Evidence for Rho-mediated agonist stimulation of phospholipase D in ratl fibroblasts. Effects of Clostridium botulinum C3 exoenzyme. J. Biol. Chem. 271, 13135-13139

25. Malcolm K. C., Ross A. H., QuU R. G., Symons M. and Exton J. H. (1994) Activation of rat liver phospholipase D by the small GTP-binding protein RhoA. J. Biol. Chem. 269, 25951-25954

26. McNeil P. L., Murphy R. F., Lanni F. and Taylor D. L. (1984) A method for incorporating macromolecules into adherent cells. J. Cell Biol. 98, 1556-1564

27. Mrtchell M. J., Laughon B. E. and Lin S. (1987) Biochemical studies on the effect of Clostridium difficile toxin $\mathrm{B}$ on actin in vivo and in vitro. Infect. Immun. 55, 1610-1615

28. Nakamura Y., Nakashima S., Kumada T., Ojio K., MiYaTA H. and Nozawa Y. (1996) Brefeldin A inhibits antigenor calcium ionophore-mediated but not PMA-induced phospholipase D activation in rat basophilic leukemia (RBL2H3) cells. Immunobiology 195, 231-242

29. NisHizUKA Y. (1992) Intracellular signaling by hydrolysis of phospholipids and activation of protein kinase C. Science 258, 607-614

30. Nobes C. D. and Hall A. (1995) Rho, Rac, and Cdc42 GTPases regulate the assembly of multimolecular focal complexes associated with actin stress fibers, lamellipodia, and filopodia. Cell 81, 53-62

31. Nobes C. D., Hawkins P., Stephens L. and Hall A. (1995) Activation of the small GTP-binding proteins Rho and Rac by growth factor receptors. J. Cell Sci. 108, 225-233

32. Ohguchi K., Banno Y., Nakashima S., Kato N., WataNABE K., LyerLy D. M. and Nozawa Y. (1996) Effects of Clostridium difficile toxin $\mathrm{A}$ and toxin $\mathrm{B}$ on phospholipase $\mathrm{D}$ activation in human promyelocytic leukemic HL60 cells. Infect. Immun. 64, 4433-4437

33. Ohguchi K., Banno Y., Nakashima S. and Nozawa Y.
(1996) Regulation of membrane-bound phospholipase D by protein kinase C in HL60 cells. Synergistic action of small GTP-binding protein RhoA. J. Biol. Chem. 271, 4366-4372

34. Ojio K., Banno Y., Nakashima S., Kato N., Watanabe K., Lyerly D. M., Miyata H. and Nozawa Y. (1996) Effect of Clostridium difficile toxin B on IgE receptor-mediated signal transduction in rat basophilic leukemia cells: inhibition of phospholipase D activation. Biochem. Biophys. Res. Commun. 224, 591-596

35. Ottlinger M. E. and LiN S. (1988) Clostridium difficile toxin B induces reorganization of actin, vinculin, and talin in cultured cells. Exp. Cell Res. 174, 215-229

36. Pearce F. L. and Messis P. D. (1982) Phosphatidic acid induces histamine secretion from rat peritoneal mast cells. Int. Arch. Allergy Appl. Immunol. 68, 93-95

37. Prepens U., Just I., von Eichel-Streiber C. and AktoRIES K. (1996) Inhibition of FceRI-mediated activation of rat basophilic leukemia cells by Clostridium difficile toxin $\mathrm{B}$ (monoglucosyltransferase). J. Biol. Chem. 271, 7324-7329

38. Ren X. D., Bokoch G. M., Traynor-Kaplan A., Jenkins G. H., Anderson R. A. and Schwartz M. A. (1996) Physical association of the small GTPase Rho with a 68kDa phosphatidylinositol 4-phosphate 5-kinase in Swiss 3T3 cells. Mol. Biol. Cell 7, 435-442

39. Schmidt M., Bienek C., Rumenapp U., Zhang C., Lummen G., Jakobs K. H., Just I., Aktories K., Moos M. and von EICHEL-STREIBER C. (1996) A role for Rho in receptorand $G$ protein-stimulated phospholipase $C$. Reduction in phosphatidylinositol 4,5-bisphosphate by Clostridium diffcile toxin B. N-S Arch. Pharmacol. 354, 87-94

40. Schmidt M., Rumenapp U., Bienek C., Keller J., von EICHEL-STREIBER C. and JAKOBS K. H. (1996) Inhibition of receptor signaling to phospholipase $\mathrm{D}$ by Clostridium difficile toxin B. Role of Rho proteins. J. Biol. Chem. 271, 2422-2426

41. Schmidt M., Rumenapp U., Nehls C., Ott S., Keller J., von Eichel-STREiber C. and JAKoBS K. H. (1996) Restoration of Clostridium difficile toxin B inhibited phospholipase D by phosphatidylinositol 4,5-bisphosphate. Eur: J. Biochem. 240, 707-712

42. Siddiqi A. R., Smith J. L., Ross A. H., Qiu R. G., Symons M. and Exton J. H. (1995) Regulation of phospholipase D in HL60 cells. Evidence for a cytosolic phospholipase D. $J$. Biol. Chem. 270, 8466-8473

43. Singer W. D., Brown H. A., Bokoch G. M. and Sternwels P. C. (1995) Resolved phospholipase D activity is modulated by cytosolic factors other than Arf. J. Biol. Chem. 270, 14944-14950

44. Takai Y., Sasaki T., Tanaka K. and NaKanishi H. (1995) Rho as a regulator of the cytoskeleton. Trends Biochem. Sci. 20, 227-231

45. YEO E. J. and ExtoN J. H. (1995) Stimulation of phospholipase $\mathrm{D}$ by epidermal growth factor requires protein kinase $\mathrm{C}$ activation in Swiss 3T3 cells. J. Biol. Chem. 270, 39803988

46. Yeo E. J., Kazlauskas A. and Exton J. H. (1994) Activation of phospholipase $\mathrm{C} \gamma$ is necessary for stimulation of phospholipase D by platelet-derived growth factor. $J$. Biol. Chem. 269, 27823-27826 